\title{
Assessment of Economics Curriculum Implementation in Colleges of Education and Secondary Schools in Oyo State
}

\author{
AdeyemiZaccheaus OJO $^{1^{*}}$, Prof. Babatunde Adeniyi ADEYEMI ${ }^{2}$ \\ ${ }^{I}$ Department of Arts and Social Science Education, Faculty of Education, Obafemi Awolowo University, Ile-Ife, \\ Osun State, Nigeria \\ ${ }^{2}$ Institute of Education, Faculty of Education Obafemi Awolowo University, Ile-Ife, Osun State, Nigeria
}

*Corresponding Author: AdeyemiZaccheaus OJO, Department of Arts and Social Science Education, Faculty of Education, Obafemi Awolowo University, Ile-Ife, Osun State, Nigeria

\begin{abstract}
The study assessed the Economics curriculum implementation in colleges of education and secondary schools in Oyo State. The study determined the relevance of Economics curriculum contents of colleges of education to the Economics curriculum contents of senior secondary schools and also determined the appropriateness of teaching strategies employed in the colleges of education and senior secondary schools in the State. Lastly, it assessed the quantity and quality of available resources for teaching of Economics in colleges of education and senior secondary schools in the State. The study employed survey research design. The population consisted of Economics Lecturers from Colleges of Education and Economics Teachers of senior secondary schools in Oyo State. The total sum of 140 respondents constituted the study sample out of which 20 Economics lecturers were from Colleges of Education and 120 Economics teachers from secondary schools in the state selected using multistage sampling procedure. Three instruments were used for the collection of the data which includes: Economics Curricula Contents Checklist (ECCC), Observation of Teaching Strategies Checklist (OTSC), and Teaching Resources Checklist (TRC). Data collected were analyzed using simple count and percentages. The results revealed that both Economics lecturers from colleges of education in Oyo State had the minimum numbers required by National Commission for College of Education (NCCE), but from the staff-students ratio perspective the findings showed 1: 57 to 1:25 as stipulated by NCCE. Economics teachers in secondary schools in Oyo State had basic requirement for teaching Economics as $83 \%$ hold (B. Ed and B.Sc. Ed) in education and $12 \%$ hold NCE while $7 \%$ teaches Economics but were not a specialist. The few available instructional materials, stationeries and non-teaching personnel required by NCCE were not adequate. The study concluded that implementation of Economics curriculum contents in Oyo State colleges of education and senior secondary schools in the state suffer from lack of diversification and combination of teaching strategies as appropriate cum inadequate used of instructional materials right from colleges of education to secondary schools.
\end{abstract}

Key words: Assessment, Economics, Curriculum implementation

\section{INTRODUCTION}

Teaching is a noble profession as well as an art of assisting students to learn through a painstaking effort from passionate instructors. It is a complex activity that emanates from fundamental knowledge requires for proficient teaching which is grounded in the liberal arts and sciences. The understanding of the art of transforming subject matters into concrete term and effective art of teaching as well as learning process is crucial to successful implementation of any curriculum. The enormity of teaching requires that teachers (lecturers/secondary schools teachers) are capable of demystifying concepts, terminology and theories in clear terms, also be able to diversify his/her methods of teaching to accommodate for diverse students in terms of individual differences, readiness, intelligent quotient, families, exposure, developments, cognitive and emotional differs greatly of which adequate provision to manage all those is central in teaching activities.

National Commission for College of Education (NCCE, 2012), was of the opinion that teaching is a dynamic profession that requires continuous review in order to address contemporary issues and challenges. That led to reviewed of curriculum being implemented both in Senior Secondary Schools (SSS) and Colleges of Education. Curriculum itself has been viewed as a series of planned learning experiences deliberately and purposefully organized to maximize the opportunities available for 
individuals to actualize their inherent genetic blue print in both formal and informal institutions (Ehindero2010). Economics curriculum hangs on the belief of the Reconstructionism Philosophical Foundation (RPF) which advocates that the curriculum should be constantly changing to meet the changes in the society, train students to engage in critical analyses, interpret, evaluate social problems and bring about constructive change. This corroborate with one of the five major tenets of reconstructionism, which are (1) Society and education require constant reconstruction; (2) programmes of study should be interdisciplinary; (3) education is being used to build a new social order and educate individuals into new citizenry behavioral roles, (4) a rationally educated humankind can direct the process of social and conscious evolution toward progressive goals and thus control humankind's destiny; and (5) educational socialization must now be both globalist and futuristic in its orientation (Gutek, 1988, Stanley, 1992; James, 1995; Ozman\& Crave, 1999) as cited by Stephen and White (2003) Actually the aim of inclusion of Economics curriculum in schools either Colleges of education or secondary schools coincide with the above tenets.

In Nigeria Education system the problem facing curriculum implementation has been a topical issue in the Educational Journals of which Economics curriculum share from the trend of the problem. Adu, Ojelabiand Adeyanju (2009) were of opinion that in senior secondary schools particularly in Oyo State, the achievement in Economics has not been good as it has been before the introduction of a new Economics syllabus which incorporated some elements of Mathematics into the subject. The situation had posed serious challenges for students in the senior secondary schools classes because as a result of their negative attitudes which they have towards Mathematics and ineffectiveness on the part of the teachers. Aromolaran (2001) was of the opinion that there are three languages which are used in teaching and communicating Economics ideas they are (i) Theory or verbal (ii) geometric or graphical and (iii) algebraic of mathematical, inadequacy in the use of any would affect conceptualization of the concept or terminology, this confirm the opinion of Ade et.al either as a students or by the teachers.

West Africa Examination Council (WAEC) Research Division Lagos gives the detail of students performance in Economics from 2001 - 2005. In 2001 out of 484,508 that sat for the examination only 94,740 (19.5\%) had credit (A1 -C6), 145,160 (30.0\%) had Pass (7-8) while 244,608(50.5\%) had F9;2002 out of 582,926 that sat for the examination only 81, 297 (14.0\%) had credit (A1 -C6), 161,175 (27.7\%) had Pass (7-8) while 339,854 (58.3\%) had F9; 2003 out of 651,426 that sat for the examination only $143,900(22.1 \%)$ had credit (A1 -C6), 202,463 (31.1\%) had Pass (7-8) while 305,063 (48.8\%) had F9; 2004 out of 732,532 that sat for the examination only $208,772(28.5 \%)$ had credit (A1-C6) 229,282 (31.3\%) had Pass (7-8) while 299,478 (40.2\%) had F9, while in 2005 out of 840.325 that sat for the examination 272,265 (32.4\%) had (A1-C6) 211,762 (25.2\%) had pass (7-8) and 356,298 (42.4\%) failed. This trend actually continue till 2009, only after 2010 the performance of those that had A1-C6 increase to $56.25 \%$, but since then the result has been fluctuating. The NCCE (2012) remark that, the general public is of the view that there is a decline in the general quality of education in the country; as it reflected in the performance of students in senior secondary schools final examination, that actually led to a review of curriculum to take place in both colleges of education and senior secondary schools curriculumso as to bridge the gap of the noticed decline.

The general problems facing Nigeria educationalsystemat all levels have been inadequate quality assurance control and accountability among others which had brought imbalance in the quality of graduates from her institutions. In Nigerian schools graduates have different levels of content knowledge acquisition in spite of regulations from NCCE and Nigeria Educational Research and Development Council (NERDC, 2008) on the curriculum. Sizeable numbers of instructors in schools today were not trained as teachers; the fact that they are graduates from university and colleges of education and were able to comprehend the contents and objectives of the curriculum make many schools principals and schools founder to employ those to teach. For instance an Economics major is termed qualify to teach Economics in secondary schools or colleges of education whereas there should be an intersection of content knowledge and pedagogical content knowledge coupled with pedagogical expertise before meaningful learning can take place.

Nigerian Colleges of Education are entrusted to prepare pre-service teachers who will teach diverse population of students; with high expectations from the government and all educational stakeholders, that those teachers after training should be able to teach and raise excellent students that are suitably incline with the paradigm shift of educational focus from an industrially-based economic system to a 
knowledge-based economic system that relies increasingly on the level of knowledge, resourcefulness and creativity of citizens to build and maintain a sustainable economy that offers reliable employment opportunities to young Nigerians.

The NCCE (2012) in order to provide solution to noticeable defects in educational system and preparation of teachers in Colleges of education from their own end have revisited their vision and mandate to maintain standards for Teacher Education at the sub- degree level and has revised the existing National Certificate on Education (NCE) Teacher Education programmes in order to provide effective teachers to meet the demand at hand. To achieve the objective NCCE (2012) provides implementation framework. (See appendix III). This study is predicated on those highlighted frameworks. The framework is in agreement with how to get objectives of inclusion of Economics curriculum in Colleges of Education and Secondary Schools. They are to train teacher who have acquired in-depth knowledge of Economics theory and applied it to solve economic problems, produce teachers who have acquired professional skill to be able to organize and teach Economics at the secondary school level in Nigeria, prepare teachers who would be able to undertake further education in Economics or related areas of study, and produce teachers who have acquired Economics skills and abilities and are able to apply them to their daily activities, as given by NCCE.

The attainment of the postulated objectives above serves as a wheel for the actualization of the objectives of inclusion of Economics in secondary schools curriculum. The effective training received under those objectives is germane to successful implementation of the curriculum. NERDC (2008) also highlighted the objectives of post-basic Economics curriculum are to enable students:

i. understand basic Economics, principle, concepts as well as the tools for sound economic analysis.

ii. contribute intelligently to discourse on economic reforms and development as they affect or would affect the generality of Nigerians.

iii. understand the structure and functioning of economic institutions.

iv. appreciate the role of public policies on national economy.

v. develop the skills and also appreciate the basis for ration economic decision.

vi. become sensitized to participate actively in national economic advancement through entrepreneurship, capital market and so on

vii. understand the role and status of Nigeria and other African countries in international economic relationships and appreciate the problems encountered by developing countries in their effort towards economic advancement.

The above objectives is achievable if the teachers are adequately equipped enough because teaching of Economics requires the use of appropriate teaching strategies in order to foster the understanding of concepts, terminologies and dug out the inherent traits in each of the learners in order to make them contribute immensely and meaningfully to the economic growth, economic planning, and economic development. Caropreso and Haggerty (2005) in Ongeri (2009), states since Economics is more of abstract expression and theoretical field of study in nature, beginning students especially found it difficult to learn the fundamental content easily. It will then be the responsibility of the lecturer or teachers to teach the subject in a manner that will make the students grasp the content well and be able to apply it in solving problems or for examination purposes. The focus should not just be covering the overloaded syllabus, or demonstration of teaching skills rather on the learning skills of students and their achievement.

The findings from researches and West African Examination Council (WAEC) Chief Examiners' reports $(2009$ - 2014) had shown that the performance of students was below average(as analyzed above) with the implication that attainment of specified objectives may be affected. The following defects/weakness were raised by the chief examiners' report; failure to expatiate points, poor graphical analysis, wrong use of terminologies, inadequate knowledge of subject matter and basic requirement of how to answer questions and teachers' omission of topics which bring about doubting the training received in content knowledge, strategies and instructional resources during their teacher training period, perhaps there was no congruence between the NCE Economics curriculum contents 
taught with (NERDC) Economics curriculum contents to be taught at the secondary schools or lecturers omitted some contents too during their training which they found difficult or new in the secondary curriculum.

In Nigeria educational system, the stereotypic ways of teaching/learning approach such as dictating note without adequate explanation and application of the concept, but expect students to regurgitate it back seem pervade the system. The need to diversify teaching methods to enhance the achievement of educational objectives should be what pre-occupies instructors at Colleges of Education and Senior Secondary Schools; as well as ability to teach the subject effectively is imperative at both levels. The need to determine how pre-service teachers and beginning teachers can best demonstrate that they have in fact acquired the requisite skills (Caldwell and Sutton 2010), beyond having desirable knowledge and understanding of what needs to be done is important. Teacher Education Implementation Taskforce (RTEIT, 2012) confirms that the biggest effect on student outcomes is the quality of teaching. Accordingly, Shulman (1986) cited in Praxis Client Conference (PCC, 2011) buttresses that the person who presumes to teach subject matter to children must demonstrate knowledge of that subject matter as a perquisite to teaching, as well as pedagogical content knowledge. The assessment of implementation of Economics Curriculum in Colleges of Education in Oyo State is central in order to sustain the hope of the nation and her stated objectives both in colleges of education and secondary schools.

\section{Statement of The Problem}

Economics as a discipline is taught in senior secondary schools as well as colleges of education with different curricula in operation. It is obvious from West African Examination Council (WAEC) Chief Examiners' reports (2009-2014)revealed that the performance of students in Economics was below average (50\%)perhaps due to teachers' omission of some topics, unable to cover syllabus and students lack of adequate knowledge of the subject matter and basic techniques to answer questions. Also, National Examination Council (NECO) Chief Examiners' report contains various set of problems such as; not covering of syllabus, mere list of point, poor knowledge of probability etc. The statistical figures shown that from (2001-2005) out of the students that enrolled 244,608(50.5\%) had F9; in 2002, $339,854(58.3 \%)$ had F9;in 2003, 305,063 (48.8\%) had F9; in 2004,299,478 (40.2\%) had F9, and 2005, 356,298 (42.4\%) failed respectively. The problem might be that perhaps these Economics teachers in secondary schools were not exposed to some curriculum contents and appropriate teaching/learning strategies during their training in the colleges of education. It therefore becomes necessary to assess the relevance of the Economics curriculum contents of colleges of education to the Economics curriculum contents of secondary school, appropriateness of teaching strategies as well as the quantity and quality of available resources used in teaching Economics in colleges of education and senior secondary schools; hence this study.

\subsection{Purpose of the Study}

The study was carried out to investigate the Economics curriculum implementation in colleges of education and secondary schools in Oyo State, teaching strategies employed and availability of the resources in teaching Economics. The specific objectives of the study are to:

(a) determine the relevance of Economics curriculum contents of colleges of education to the Economics curriculum contents of senior secondary schools in Oyo State;

(b) determine the appropriateness of teaching strategies employed in the colleges of education and senior secondary schools in the State; and

(c) assess the quantity and quality of available resources for teaching of Economics in colleges of education and senior secondary schools in the State.

\subsection{Research Questions}

(i) To what extents are the Economics curriculum contents of colleges of education relevanttothe Economics curriculum contents of senior secondary school in Oyo State?

(ii) What is the degree of appropriateness of the teaching strategies employed in the colleges of education and senior secondary school in Oyo State? 
(iii) How adequate are the quantity and quality of available resources for teaching Economics in colleges of education and senior secondary schools in Oyo State?

\section{METHOdOLOGY}

The study adopted survey research design because the study seeks to establish the relatedness that exists between the economics curriculum content implementation in colleges of education with senior secondary schools, also for instructional strategies, quantity and quality of available resources. The population for the study consisted of Economics lecturers in colleges of education in Oyo State and Economics teachers in senior secondary schools in Oyo State. The study sample consisted of 140 respondents comprising 20 lecturers from colleges of education and 120 secondary schools Economics teachers. One senatorial district was selected out of the three senatorial districts in the State using simple random sampling technique. From the 13 Local Government Areas (LGAs) in the senatorial district, four LGAs were selected with 15 schools from each LGA and two Economics teachers from each school using simple random sampling technique. Simple random sampling technique was employed in selecting 20 lecturers of Economics (10 from each of the two government colleges of education in Oyo State).

Three instruments were used for this study. They are: Economics Curricula Contents Checklist (ECCC), Observation of Teaching Strategies Checklist (OTSC), and Teaching Resources Checklist (TRC). The ECCC was used by the researcher to determine the relatedness of the Economics curriculum contents used in colleges of education and senior secondary schools by ticking the appropriateness of relatedness under the fully captured scored as 3, partially captured scored as 2 and not captured/not related scored as 1 . Content analysis was used and rated as $70 \%-100 \%$ was said to be greatly relevant; $50 \%$ - 69\% was said to moderately relevant; $35 \%-49 \%$ was said partially relevant and $0 \%-34 \%$ not relevant.

OTSC was used to determine the appropriateness of teaching strategy(s) employed in teaching the course content selected for the class that day, the strategy(s) usedwere ticked and scored 2 and not used scored as 1, while assessment rating form were used to determine appropriateness of teaching strategies employed merged with OTSC and rated as 80\% - 99\% (Most Appropriate); 60\% - 79\% (Adequately Appropriate); 50\% - 59\% (Appropriate); $40 \%$ - 49 (Partially Appropriate) and 0\% 39\% (Not Appropriate)

TRC was used by the investigators to assess the quantity and quality of available resources used in teaching Economics in term of teaching staff and non-teaching staff and detail about lecturer was collected in line with NCCE regulation. Number of available facilities were considered as number available, used occasionally, not used, number in good state and number obsolete, while books in library were also assessed by obtaining number available books, number of students that assessed it, number of obsolete books, students-ratio to books:- normal 1: 10, below 1:10 books and above 1:10 books.

The ECCC, OTSC and TRC were validated by the expert in the field of Curriculum Development from the Department of Arts and Social Science Education, Obafemi Awolowo University. The study was carried out in six weeks as against four week projected. In the first week of the exercise two colleges of education were visited for the purpose of seeking permission for the observation of the lecturer and their resources as well as secondary schools from two local governments. The second week was used to observe the teachers teaching and assessed their resources on ground in senior secondary schools in Oyo State. The third week the researcher went back to Colleges of education following their time table simultaneously as well as reaching others secondary schools. In the fourth week other two local governments were visited to carry out the exercise in all the schools sampled. Fifth week was also used in going back to colleges of Education to assess other lecturer who did not have lecture at the first arrangement and other secondary school was cumulated in week six. Data collected was analyzed by using descriptive statistics. Simple percentage was used to provide answer to research question one and research question two and frequency count was used to provide answer for the research question three.

\section{RESUlts}

Research Question 1: To what extent are the Economics curriculum contents of colleges of education relevant to Economics curriculum contents of senior secondary school in Oyo State? 
Assessment of Economics Curriculum Implementation in Colleges of Education and Secondary Schools in Oyo State

In answering the research question one, a research instrument was used by the researcher to determine the relatedness of the Economics curricula used in colleges of education and senior secondary schools by ticking the appropriateness of relatedness under fully captured - scored as 3, partially capturedscored as 2 and not captured/not related scored as 1 ,

Table1. The relatedness of Economics Curriculum Contents of Colleges of Education to Economics Curriculum Contents of Secondary School in Oyo State

\begin{tabular}{|c|c|c|c|}
\hline SSS Curriculum Contents & $\begin{array}{l}\text { Fully } \\
\text { captured } \\
(3)\end{array}$ & $\begin{array}{l}\text { Partially } \\
\text { captured } \\
(2)\end{array}$ & $\begin{array}{l}\text { Not } \\
\text { captured } \\
(1)\end{array}$ \\
\hline Meaning of Economics and related concepts. & $\checkmark$ & & \\
\hline Basic tools of economics & $\checkmark$ & & \\
\hline Concept of demand and supply & $\checkmark$ & & \\
\hline Theory of production & $\checkmark$ & & \\
\hline The Production Possibility Curve (PPC) & $\checkmark$ & & \\
\hline Cost concepts & $\checkmark$ & & \\
\hline Revenue concepts & $\checkmark$ & & \\
\hline $\begin{array}{l}\text { Meaning of economic system, basic economic problem of } \\
\text { society, types and features. }\end{array}$ & $\checkmark$ & & \\
\hline Business organization(Firm and Industry) & $\checkmark$ & & \\
\hline Population, Labour market, Human Capital Development & $\checkmark$ & & \\
\hline $\begin{array}{l}\text { Structure of Nigerian Economy, Nature of the Nigerian } \\
\text { Economy, Agriculture, Mining, Petroleum and the Nigerian } \\
\text { Economy, Manufacturing and Construction, Service }\end{array}$ & $\checkmark$ & & \\
\hline $\begin{array}{l}\text { Consumer Behaviour, Price Determination and Market } \\
\text { Structures, }\end{array}$ & $\checkmark$ & & \\
\hline $\begin{array}{l}\text { Nigerian Economy and Major Natural Resources: Industries in } \\
\text { Nigeria, Agriculture }\end{array}$ & $\checkmark$ & & \\
\hline $\begin{array}{l}\text { National Income and Public Finance: Elementary treatment of } \\
\text { fiscal policy, Balanced and unbalanced budget, Elements of } \\
\text { national Income Accounting }\end{array}$ & $\checkmark$ & & \\
\hline $\begin{array}{l}\text { Financial Institution and Regulatory Agencies: Meaning, Types } \\
\text { of financial institutions and their functions, agencies that regulate } \\
\text { the financial markets, Functions and Role of Regulatory } \\
\text { Agencies }\end{array}$ & $\checkmark$ & & \\
\hline $\begin{array}{l}\text { Money: Meaning, characteristics, functions, Demand for and } \\
\text { supply of money and Inflation/Deflation }\end{array}$ & $\checkmark$ & & \\
\hline Distributive Trade: Channels of Distribution & $\checkmark$ & & \\
\hline Business Finance: Instruments of Business Finance & $\checkmark$ & & \\
\hline International Trade and Balance of Payments & $\checkmark$ & & \\
\hline $\begin{array}{l}\text { Development Economics: Economic growth and development, } \\
\text { Economic development planning }\end{array}$ & $\sqrt{ }$ & & \\
\hline International Economics Organizations & $\checkmark$ & & \\
\hline $\begin{array}{l}\text { Applied Economics and contemporary Economic Organizations: } \\
\text { Current Economic plans MDG's NEEDS, Vision2020, Economic } \\
\text { Development challenges, Economic Reforms Programmes. }\end{array}$ & $\checkmark$ & & \\
\hline $\begin{array}{l}\text { Total number of SSS Economics Curriculum contents } \\
\text { capture in Colleges of Education Economics Curriculum } \\
\text { Contents }\end{array}$ & 300 & $\mathbf{0}$ & $\mathbf{0}$ \\
\hline Percentage of SSS ECC captured in COE ECC & $100 \%$ & $\mathbf{0 \%}$ & $\mathbf{0 \%}$ \\
\hline
\end{tabular}

Table 1showed that not captured was zero (0), partially capture was zero (0) while fully capture was scored as 300 meaning that the Economics contents in senior secondary schools was completely capture in the Colleges of Education. The result showed that the Economics curriculum contents of secondary schools were greatly relevant to Economics curriculum contents in Colleges of Education with $100 \%$ level of relatedness. This suggests that Economics Curriculum in secondary schools should be easy for implementation because it was duly covered in the cause of teachers training programme in colleges of Education. The above result was not in full compliance with Bakare (2014) where only $56.8 \%$ of curriculum contents of computer were fully captured in college of education in 
related to Junior Secondary Schools Computer Science Education while 35.1\% were reported not captured at all.

Research Question 2: What is the degree of appropriateness of the teaching strategies employed in the colleges of education and senior secondary school in Oyo State?

In order to provide solution the above research question a research instrument called Observation of Teaching Strategies Checklist was designed (OTSC) both for Senior Secondary Schools and Colleges of Education in Oyo State and Assessment Rating Form for teaching practice developed by Faculty of Education Obafemi Awolowo University was adapted and merged to determine the degree of appropriateness of the chosen strategies by Economics Teachers in secondary schools and Economics Lectures from Colleges of Education. The OTSC was were scored as 1 for use and not use was scored as 0 , while adapted assessment rating form was used to determine level of appropriateness of the teaching strategies adopted and rated as follow 80\% - 100\% (Most Appropriate); 60\% - 79\% (Adequately Appropriate); 50\% - 59\% (Appropriate); 40\% - 49\% (Partially Appropriate) and 0\% 39\% (Not Appropriate)

Table2a. The teaching strategies employed in Colleges of Education

\begin{tabular}{|c|c|c|c|c|c|c|c|}
\hline $\begin{array}{l}\text { Recommended } \\
\text { Strategy }\end{array}$ & Used & $\begin{array}{ll}\% & \text { of } \\
\text { used }\end{array}$ & $\begin{array}{l}\text { Most } \\
\text { Appro }\end{array}$ & Adeqt Appro & Appro & $\begin{array}{l}\text { Partially } \\
\text { Appro }\end{array}$ & $\begin{array}{c}\text { Not } \\
\text { Appro }\end{array}$ \\
\hline Lecture & 10 & $50 \%$ & -- & $4(20 \%)$ & $6(30 \%)$ & & \\
\hline Tutorial & -- & -- & -- & -- & -- & -- & -- \\
\hline Field trips & -- & & & & & & \\
\hline Discussion & 6 & $30 \%$ & & $4(20 \%)$ & $2(10 \%)$ & & \\
\hline Games & -- & & & & & & \\
\hline Stimulation & -- & & & & & & \\
\hline \multicolumn{8}{|c|}{ Not Recommended by NCCE } \\
\hline Seminar & -- & & & & & & \\
\hline Project & -- & & & & & & \\
\hline Inquiry & -- & -- & -- & & & & \\
\hline $\begin{array}{l}\text { Problem -based } \\
\text { method }\end{array}$ & -- & & & & & & \\
\hline $\begin{array}{l}\text { Collaborative } \\
\text { method }\end{array}$ & -- & & & & & & \\
\hline $\begin{array}{l}\text { Team-based } \\
\text { method }\end{array}$ & -- & & & & & & \\
\hline \multicolumn{8}{|c|}{ Combination of strategies } \\
\hline $\begin{array}{ll}\text { Tutorial } & \& \\
\text { Discussion } & \end{array}$ & 2 & $10 \%$ & $1(5 \%)$ & $1(5 \%)$ & & & \\
\hline $\begin{array}{l}\text { Inquiry } \\
\text { \&Tutorial }\end{array}$ & 2 & $10 \%$ & $1(5 \%)$ & & $1(5 \%)$ & & \\
\hline TOTAL & 20 & $100 \%$ & $2(10 \%)$ & $9(45 \%)$ & $9(45 \%)$ & & \\
\hline
\end{tabular}

Table 2a which indicated the teaching strategies employed by Economics Lecturers in Colleges of Education and the degree of appropriateness was depicted above. 10 Lecturers used lecture strategy amount to $50 \%$ out of which $4(20 \%)$ indicated adequately appropriate wand $6(30 \%)$ was said to appropriate. Although50\% of the lecturers that utilize this method did not score well in the use of instructional materials, which has in a way affect their scores. Six (6) 30\%lecturers used discussion strategy out of which 4 (20\%) indicated adequately appropriate and $2(10 \%)$ appropriate. While some that used combination of strategies cumulate to $20 \%$; such as Tutorial and discussion strategies as well as Inquiry and Tutorial. 2 (10\%) used tutorial and discussion out of which 1(5\%) was said to be most appropriately used while $1(5 \%)$ adequately appropriate. For Inquiry and tutorial $2(10 \%)$ used it out of which $1(5 \%)$ was said to be most appropriately used and 1(5\%) appropriate. It was only those that used combination of the strategies that scored well in the used of instructional strategies because the topic taught was mathematical in nature

Table2b. The teaching strategies employed in Secondary Schools in Oyo State

\begin{tabular}{|c|c|c|c|c|c|c|c|}
\hline $\begin{array}{l}\text { Strategy } \\
\text { employed }\end{array}$ & Used & \begin{tabular}{|l|}
$\%$ \\
used
\end{tabular} & $\begin{array}{l}\text { Most } \\
\text { Appro }\end{array}$ & AdeqtAppro & Appro & \begin{tabular}{|l|} 
Partially \\
Appro
\end{tabular} & \begin{tabular}{|l} 
Not \\
Appro
\end{tabular} \\
\hline
\end{tabular}


Assessment of Economics Curriculum Implementation in Colleges of Education and Secondary Schools in Oyo State

\begin{tabular}{|c|c|c|c|c|c|c|c|}
\hline Collaborative & - & - & - & - & - & - & - \\
\hline $\begin{array}{l}\text { Learner- } \\
\text { oriented }\end{array}$ & - & - & - & - & - & - & - \\
\hline Field trips & - & - & - & - & - & - & - \\
\hline Interactive & 61 & $50.83 \%$ & - & $13(10.83 \%)$ & $19(15.83 \%)$ & $20(16,75 \%)$ & $9(7.5 \%)$ \\
\hline $\begin{array}{l}\text { Concept } \\
\text { mapping }\end{array}$ & - & - & - & - & - & - & - \\
\hline $\begin{array}{l}\text { Cooperative } \\
\text { learning }\end{array}$ & - & - & - & - & - & - & - \\
\hline Field officers & - & - & - & - & - & - & \\
\hline $\begin{array}{l}\text { Resources } \\
\text { person }\end{array}$ & - & - & - & - & - & - & - \\
\hline \multicolumn{8}{|c|}{ Not recommended by NERDC } \\
\hline $\begin{array}{l}\text { Problem - } \\
\text { based method }\end{array}$ & -- & -- & - & - & & - & - \\
\hline Inquiry & -- & -- & - & - & -- & - & - \\
\hline $\begin{array}{l}\text { Team-based } \\
\text { method }\end{array}$ & - & - & - & - & - & - & - \\
\hline Lecture & 38 & $31.67 \%$ & - & $2(1.67 \%)$ & $4(3.33 \%)$ & $24(20 \%)$ & $8(6.67 \%)$ \\
\hline Discussion & 18 & $15 \%$ & - & - & $7(5.83 \%)$ & $10(8.33 \%)$ & $1(0.83 \%)$ \\
\hline \multicolumn{8}{|c|}{ Combination of strategies } \\
\hline $\begin{array}{l}\text { Inquiry \& } \\
\text { Interactive }\end{array}$ & 2 & $1.67 \%$ & & & $2(1.67 \%)$ & & \\
\hline $\begin{array}{l}\text { Prob based M } \\
\text { \& Interactive }\end{array}$ & 1 & $0.83 \%$ & & & $1(0.83 \%)$ & & \\
\hline Total & 120 & $100 \%$ & & $15(12.50 \%)$ & $33(27.50 \%)$ & $54(45 \%)$ & $18(15 \%)$ \\
\hline
\end{tabular}

Table $2 \mathrm{~b}$ indicates the teaching strategies employed by Economics Teachers in Secondary Schools and the degree of appropriateness was depicted above. 61Economics teachers employed interactive strategy as part of recommended by NERDC which amount to $50.83 \%$ out of which $13(10.83 \%)$ indicated adequately appropriate when used and $19(15.83 \%)$ was said to appropriate, $20(16.75 \%)$ was partially appropriate and $9(7.5 \%)$ said to not appropriately used.38 (31.67\%) Economics teachers used lecture strategy to teach in secondary schools which is part of non- recommended by NERDC, 2(1.67\%) used it as adequately appropriate; 4 (3.33\%) used it appropriately; 24 (20\%) said partially appropriate and $8(6.67 \%)$ said not appropriately used. Discussion strategy was also employed by 18 (15\%) Economics teachers among which 7 (5.83\%) said to be appropriately used; 10 $(8.33 \%)$ partially used and $1(0.83 \%)$ said not appropriately used. Whereas we have some that used the combination of strategies, Inquiry and Interactive strategies were used by two Economics teacher [2 (1.67\%)] which said to be appropriately. Problem based method and Interactive was used by a teacher $[1(0.83 \%)]$ it was used appropriately.

From the result presentation it can be deduced that $56(46.67 \%)$ used non recommended strategies by NERDC which was almost half of the population sampled. Only 13 (10.83) actually were averagely effective, 34 (28.33\%) were partially effective which tend to have negative implication on students learning and performance although the performance was not the focused here but from the observation and learners response during the teaching it was glaring noticed. Some of them could have done better if utilized instructional materials couple with the strategies but majority did not. For the recommended strategies only interactive were employed. 32 Economics teachers out of 61 users actually did well and facilitate learning; why 20 (16.75) Economics were partially effective in its used which has great influence on the learning process because that amount to $1 / 3$ of the users of the strategy.

All together out of 120 Economics teachers that employed various strategies 15 (12.5\%) were said to be adequately appropriate in the used of them; $33(27.50 \%)$ were appropriate; 54(45\%) were partially appropriate and $18(15 \%)$ said not appropriately at all. We can actually deduced that the percentage of those teachers that were actually good (adequately appropriate \& Appropriate) [48 (40\%)] less than partially appropriate with $54(45 \%)$ while $18(15 \%)$ showed not appropriate. That suggested that the strategies employed by the Economics teachers in senior secondary schools in Oyo State has great negative influence on the performance of the students as reported by the Chiefs of Examiners' 
Research Question 3: How adequate are the quantity and quality of available resources for teaching Economics in colleges of education and senior secondary schools in Oyo State?

In answering the research question three, Teaching Resources Checklist (TRC) was employed in line with the recommended resources by NCCE. It has various sections such as personnel, facilities and available materials in the library. In term of personnel it is divided into two: Academic Staff and Nonacademic staff (Clerk, Computer operator and Laboratory attendant). The NCCE recommended that at least Eight Lecturer should be at the Economics department with Staff-Students ratio should be1:25.

At Federal Colleges of Education (Special) Oyo Economics department has Eleven (11) lecturers which suggested that they have adequate numbers of lecturers in compares with minimum requirement of eight lecturers as stipulated by NCCE. But if we are to look at it from the staffstudents ratio, from part one to part three the total number of the students of Economics is 630. This suggested that the Staff- students' ratio is 1:57 that was actually above 1: 25 recommended. In order to meet up with the required ratio if the number of students will remain at 630 it implies that there must be 24 lecturers in the department or students' population will be reduced to 275 . Looking at it from that end the conclusion could be there was inadequate in the availability of the number of lecturers in Federal College of Education (Special) Oyo, but in term of quality all of them meet up with the NCCE requirement that each should possess NCE or post graduate as minimum for teaching in Colleges of Education. Out of eleven lecturers there two were pursuing their Ph.D, six M. Sc. Economics while three had M. A. Ed. Economics. In term of non - academic staff; one clerk available the same act as computer operator and laboratory attendant, which implies inadequacy in quantity and quality wise. For facilities which includes classrooms, Equipment and Staff office. The analysis of how availability is presented in the table below

Table3a. Facilities: Classroom, Equipment, and Staff Office (Oyo Special)

\begin{tabular}{|c|c|c|c|c|c|c|c|}
\hline $\mathrm{s} / \mathrm{n}$ & Items & $\begin{array}{c}\text { No } \\
\text { Available }\end{array}$ & $\begin{array}{l}\text { Used } \\
\text { often }\end{array}$ & $\begin{array}{c}\text { Used } \\
\text { occasionally }\end{array}$ & $\begin{array}{l}\text { Not } \\
\text { used }\end{array}$ & $\begin{array}{l}\text { No in } \\
\text { good state }\end{array}$ & $\begin{array}{l}\text { No of } \\
\text { obsolete }\end{array}$ \\
\hline 1 & Lecture room. & 6 & $\checkmark$ & --- & --- & 6 & --- \\
\hline 2 & Economics room & 2 & $\checkmark$ & --- & --- & 2 & --- \\
\hline 3 & $\begin{array}{l}\text { Economics wall } \\
\text { maps of Nigeria, }\end{array}$ & 0 & --- & --- & --- & --- & --- \\
\hline 4 & $\begin{array}{l}\text { Economics wall } \\
\text { map of Africa }\end{array}$ & 0 & --- & $\begin{array}{ll}-- \\
\end{array}$ & $\begin{array}{ll}-- \\
\end{array}$ & --- & $\begin{array}{ll}-- \\
\end{array}$ \\
\hline 5 & $\begin{array}{l}\text { Economics wall } \\
\text { map of World }\end{array}$ & 0 & --- & --- & --- & --- & --- \\
\hline 6 & Radios, & 0 & --- & --- & --- & --- & --- \\
\hline 7 & Tape recorder & 0 & --- & --- & --- & --- & --- \\
\hline 8 & Cassettes & 0 & --- & --- & --- & --- & --- \\
\hline 9 & Projector & 0 & --- & --- & --- & --- & --- \\
\hline 10 & Computer set & 14 & --- & $\checkmark$ & --- & 14 & --- \\
\hline 11 & Typewriter & 0 & --- & --- & $\begin{array}{ll}--- \\
\end{array}$ & --- & --- \\
\hline 12 & $\begin{array}{l}\text { Others instrument } \\
\text { aids }\end{array}$ & 0 & $\begin{array}{ll}-- \\
\end{array}$ & $\begin{array}{l}-- \\
\end{array}$ & --- & $\begin{array}{ll}--- \\
\end{array}$ & $\begin{array}{l}-- \\
\end{array}$ \\
\hline 13 & Senior staff office & 2 & $\checkmark$ & --- & --- & --- & --- \\
\hline 14 & $\begin{array}{l}\text { Reproduction } \\
\text { machine }\end{array}$ & 0 & -- & --- & --- & --- & --- \\
\hline
\end{tabular}

Table 3a present the availability of the facilities in term of classroom, equipment and staff office as recommended by NCCE. The college has six big lecture rooms which was adequate and conducive for learning. As noticed the college has two Economics room as required, 14 computer sets were on ground but used occasionally and lecturer have not been actually making use of it in teaching learning process. All the others facilities were not in place such as Economics wall maps, projector, and taperecorder e.tc. That suggests inadequacy both in quality and quantity. That was in agreement with findings of Uma, Obidike and Ogwuru (2013) that the inadequacy is not limited to Colleges of Education alone it cut across all levels of education in Nigeria are deficient in the provision of teachers, principal infrastructure that includes instructional materials and resort centers. Edem (2004) also found that most of the colleges lack basic facilities.

Table3b. Available Materials in the Library (Oyo Special)

\begin{tabular}{|l|l|l|l|l|l|l|}
\hline s/n & Subject & No & No & of & $\%$ of no in & Student -ratio to books \\
\hline
\end{tabular}


Assessment of Economics Curriculum Implementation in Colleges of Education and Secondary Schools in Oyo State

\begin{tabular}{|c|c|c|c|c|c|c|c|}
\hline & Areas & Available & obsolete & good used & $\begin{array}{l}\text { Normal 1: } \\
10 \text { books }\end{array}$ & $\begin{array}{l}\text { Below 1: } \\
10 \text { books }\end{array}$ & $\begin{array}{l}\text { Above } \\
1: 10 \text { books }\end{array}$ \\
\hline 1. & $\begin{array}{l}\text { Micro } \\
\text { Economics }\end{array}$ & 55 & 4 & $94.44 \%$ & --- & --- & $\checkmark$ \\
\hline 2. & $\begin{array}{l}\text { Macro } \\
\text { Economics }\end{array}$ & 60 & 5 & $91.67 \%$ & --- & --- & $\checkmark$ \\
\hline 3. & $\begin{array}{l}\text { Applied } \\
\text { Economics }\end{array}$ & 35 & 5 & $85.71 \%$ & --- & --- & $\checkmark$ \\
\hline 4. & $\begin{array}{l}\text { Labour } \\
\text { Economics }\end{array}$ & 25 & -- & $100 \%$ & --- & --- & $\checkmark$ \\
\hline 5 & $\begin{array}{l}\text { Development } \\
\text { Economics }\end{array}$ & 35 & 9 & $74.29 \%$ & --- & --- & $\checkmark$ \\
\hline 6. & $\begin{array}{l}\text { International } \\
\text { Economics }\end{array}$ & 20 & -- & $100 \%$ & --- & --- & $\checkmark$ \\
\hline 7. & $\begin{array}{l}\text { History of } \\
\text { Economics } \\
\text { Thought }\end{array}$ & 50 & 15 & $70 \%$ & --- & --- & $\checkmark$ \\
\hline 8. & Statistics & 25 & --- & $100 \%$ & --- & --- & $\checkmark$ \\
\hline 9. & $\begin{array}{l}\text { Business } \\
\text { Economics }\end{array}$ & 25 & --- & $100 \%$ & --- & --- & \\
\hline 10. & $\begin{array}{l}\text { Economics } \\
\text { Methodology }\end{array}$ & 10 & --- & $100 \%$ & --- & --- & $\checkmark$ \\
\hline 11. & $\begin{array}{l}\text { Mathematics } \\
\text { Economics }\end{array}$ & 20 & --- & $100 \%$ & --- & --- & $\checkmark$ \\
\hline \multirow[t]{2}{*}{12.} & Others & 88 & 20 & $77.27 \%$ & --- & --- & $\checkmark$ \\
\hline & Total & 448 & 58 & & -- & -- & \\
\hline
\end{tabular}

Table 3 b showed that 448 books were available in the library for different courses out of which 58 were obsolete. For each of the textbook subject areas the student-ratio is above 1:10 contrary to $1: 10$ books (one student to ten books).Department do not have any copy of text books for teachers of students used. The conclusion here would be that there is inadequacy availability of the available materials in the library of Oyo Special.

At Emmanuel Alayande College of Education Oyo the total number of lecturers is fourteen (14) which was said to be above the Eight minimum required. Three of them had $\mathrm{Ph}$. $\mathrm{D}$ while the rest eleven hold master in Economics of which all of them had the teaching minimum qualification such as NCE, PGD and B.Sc. Ed respectively. From the Staff - Students ratio perspective the finding show 14:900 (1:64.3) which was above the 1:25 recommended by NCCE suggest that there were inadequacy in the number of lecturers to the available students in the school. But if going by eight (8) require to fourteen (14) available one can said that lecturers availability is adequate. In terms of nonacademic staff; one clerk available the same act as computer operator and laboratory attendant, which implies inadequacy in quantity and quality wise. For facilities which includes classrooms, Equipment and Staff office. The analysis of how availability is presented in the table below.

Table3c. Facilities: Classroom, Equipment, and Staff Office (Alayande)

\begin{tabular}{|l|l|l|l|l|l|l|l|}
\hline s/n & Items & $\begin{array}{c}\text { No } \\
\text { Available }\end{array}$ & $\begin{array}{l}\text { Used } \\
\text { often }\end{array}$ & $\begin{array}{c}\text { Used } \\
\text { occasionally }\end{array}$ & Not used & $\begin{array}{l}\text { No } \\
\text { good state }\end{array}$ & $\begin{array}{c}\text { No } \\
\text { obsolete }\end{array}$ \\
\hline 1 & Lecture room. & 4 & $\checkmark$ & --- & --- & 4 & --- \\
\hline 2 & Economics room & 6 & $\checkmark$ & --- & --- & 6 & --- \\
\hline 3 & $\begin{array}{l}\text { Economics wall } \\
\text { maps of Nigeria, }\end{array}$ & 1 & --- & --- & --- & 1 & --- \\
\hline 4 & $\begin{array}{l}\text { Economics wall } \\
\text { map of Africa }\end{array}$ & 1 & --- & --- & --- & 1 & --- \\
\hline 5 & $\begin{array}{l}\text { Economics wall } \\
\text { map of World }\end{array}$ & 0 & --- & --- & --- & --- & --- \\
\hline 6 & Radios, & 0 & --- & --- & --- & --- & --- \\
\hline 7 & Tape recorder & 1 & --- & --- & --- & --- & --- \\
\hline 8 & Cassettes & 0 & --- & --- & --- & --- & --- \\
\hline 9 & Projector & 0 & --- & --- & --- & --- & --- \\
\hline 10 & Computer set & 9 & --- & $\checkmark$ & --- & 9 & --- \\
\hline
\end{tabular}




\begin{tabular}{|l|l|l|l|l|l|l|l|}
\hline 11 & Typewriter & 0 & --- & --- & --- & --- & -- \\
\hline 12 & $\begin{array}{l}\text { Others instrument } \\
\text { aids }\end{array}$ & 0 & --- & --- & --- & --- & -- \\
\hline 13 & Senior staff office & 4 & $\checkmark$ & --- & --- & 4 & --- \\
\hline 14 & $\begin{array}{l}\text { Reproduction } \\
\text { machine }\end{array}$ & 1 & -- & --- & --- & 1 & --- \\
\hline
\end{tabular}

Table $3 \mathrm{c}$ showed that the classroom available was said to be adequate in related to the requirement by NCCE. Four classrooms were on ground and suitable for learning, six Economics room used often and were all in good condition. One improvise Economics wall maps of Nigeria and that of Africa were available, nine computer set both in good condition but used occasionally, one reproduction machine and four senior staff office while others equipment were not available and were vital to the curriculum implementation. The findings correlate with the findings of Gathumbi and Mosoti (2015) that unavailability, inadequacy and inappropriateness of the resources, equipment and materials in the centre has resulted inadequate professional training made teachers to unable prepare, used instructional materials and use of scheme of work which affect the curriculum implementation. Oladejo, Olosunde, Ojebisi, and Isola (2011) reveals that lack of adequate professional training as a major problem militating against the effective use of local resources for science. Shuaibu and Shuaibu (2015) identified problem related to instructional material in the cause of curriculum implementation such as finance, personnel, educational resources missing in the schools and instructional materials are not on ground at all. As pointed out all was encounter in the course of this study across the schools visited.

Table3d. Available Materials in the Library (Alayande)

\begin{tabular}{|c|c|c|c|c|c|c|c|}
\hline \multirow[t]{2}{*}{$\mathrm{s} / \mathrm{n}$} & \multirow{2}{*}{$\begin{array}{l}\text { Subject } \\
\text { Areas }\end{array}$} & \multirow{2}{*}{$\begin{array}{c}\text { No } \\
\text { Available }\end{array}$} & \multirow{2}{*}{$\begin{array}{c}\text { No of } \\
\text { obsolete }\end{array}$} & \multirow{2}{*}{$\begin{array}{l}\% \text { of no in } \\
\text { good use }\end{array}$} & \multicolumn{3}{|c|}{ Student -ratio to books } \\
\hline & & & & & $\begin{array}{l}\text { Normal 1: } \\
10 \text { books }\end{array}$ & $\begin{array}{l}\text { Below 1: } \\
10 \text { books }\end{array}$ & $\begin{array}{l}\text { Above } \\
1: 10 \text { books }\end{array}$ \\
\hline 1. & $\begin{array}{l}\text { Micro } \\
\text { Economics }\end{array}$ & 65 & 5 & $92.31 \%$ & --- & --- & $\checkmark$ \\
\hline 2. & $\begin{array}{l}\text { Macro } \\
\text { Economics }\end{array}$ & 70 & 6 & $91.43 \%$ & --- & --- & $\checkmark$ \\
\hline 3. & $\begin{array}{l}\text { Applied } \\
\text { Economics }\end{array}$ & 40 & 5 & $87.5 \%$ & --- & --- & $\checkmark$ \\
\hline 4. & $\begin{array}{l}\text { Labour } \\
\text { Economics }\end{array}$ & 49 & -- & $100 \%$ & --- & --- & $\checkmark$ \\
\hline 5 & $\begin{array}{l}\text { Development } \\
\text { Economics }\end{array}$ & 62 & 15 & $75.81 \%$ & --- & --- & $\checkmark$ \\
\hline 6. & $\begin{array}{l}\text { International } \\
\text { Economics }\end{array}$ & 50 & -- & $100 \%$ & --- & --- & $\checkmark$ \\
\hline 7. & $\begin{array}{l}\text { History of } \\
\text { Economics } \\
\text { Thought }\end{array}$ & 75 & 20 & 73.33 & --- & --- & $\checkmark$ \\
\hline 8. & Statistics & 60 & --- & $100 \%$ & --- & --- & $\checkmark$ \\
\hline 9. & $\begin{array}{l}\text { Business } \\
\text { Economics }\end{array}$ & 38 & --- & $100 \%$ & --- & --- & \\
\hline 10. & $\begin{array}{l}\text { Economics } \\
\text { Methodology }\end{array}$ & 24 & $\begin{array}{ll}-- \\
\end{array}$ & $100 \%$ & --- & $-\overline{--}$ & $\checkmark$ \\
\hline 11. & $\begin{array}{l}\text { Mathematics } \\
\text { Economics }\end{array}$ & 33 & --- & $100 \%$ & --- & --- & $\checkmark$ \\
\hline 12. & Others & 250 & 40 & $84 \%$ & --- & --- & $\checkmark$ \\
\hline & Total & 816 & 91 & & --- & -- & \\
\hline
\end{tabular}

Table $3 \mathrm{~d}$ revealed 816 books were available in the school library for different courses out of which 91 were obsolete while 63 books were available at the departmental level all in good terms(comprises of 10 Microeconomics, 10 Macroeconomics, 5 Applied Economics,4Labour Economics, 7 Development economics, 3 International Economics, 3 History of Economics Thought, 15 Statistics, Business Economics, 3 Economics Methodology and 6 Mathematics Economics. For each of the textbook subject areas the student-ratio is above 1 . The conclusion here would be that there was inadequate availability of the available materials in the Emmanuel Alayande College of Education if compares to 
the NCCE requirement. Majority of the textbook were of good quality and up to date. Edem, (2004) reported that the reason for the non-availability and state of facilities in the colleges was given as limited funding by the government. Actually researcher found out the reasons in those schools as well the answer provide was the same with Edem (2004), Mkpa, (2001) findings was in agreement with the ratio of available textbook to students' population, he found that the number of students exceeds the facilities.

In answering the research question three in related to how adequate are the quantity and quality of available resources for teaching Economics in senior secondary schools in Oyo State, Teaching Resources Checklist (TRC) was employed in line with the recommended resources by NERDC which was divided into two aspect the personnel and availability of facilities/stationeries. Table 4.3e reveal the qualification of the personnel to make us determined the extent of their quality.

Table3e. Qualification of Economics Teachers in Senior Secondary schools in Oyo State

\begin{tabular}{|l|l|l|}
\hline Qualification & Number & Percentage \\
\hline NCE & 14 & $11.67 \%$ \\
\hline B. Ed/ B. Sc. Ed Economics & 99 & $82.5 \%$ \\
\hline M. Sc Economics/ M. A. Ed Economics & 0 & $0 \%$ \\
\hline Ph. D Economics & 0 & $0 \%$ \\
\hline Others (outside Economics) & 7 & $5.83 \%$ \\
\hline Total & 120 & $100 \%$ \\
\hline
\end{tabular}

Table 3e, the result reveal that $11.67 \%$ (14) teachers' possessed NCE certificate with Economics and others teaching subject like computer, Mathematics, Social studies and Geography while $82.5 \%$ (99) teachers' possessed B. Ed/B.Sc. Economics across the four local governments chosen for the study and 5.83\% (7) hold certificate which do not have to do with Economics yet assisting in teaching the subject. Based on the qualification it can be conclude that most of Economics teacher in Oyo secondary schools have adequate quality to qualify them for teaching as $72.5 \%$ (87) have teaching experience that range from 5 -13years and above. In terms of quantity most of senior secondary schools in Oyo State do not have up to two Economics teachers which had made the weeks for the study to extend beyond the stipulated weeks in searching for schools that meet up with the selection mode for the exercise. The findings share the same view with School Reform New Staff (2001) opinion cited in Adegbile and Adeyemi (2008) that better qualified and more experience teachers tend to move to schools with higher achieving students as well as Donaldson and Johnson (2011) revealed that teacher experience has significant effect on students' achievement.

Table3f. Available Facilities and Stationeries at Secondary Schools in Oyo State

\begin{tabular}{|l|l|l|l|l|l|l|l|}
\hline S/N & Items & $\begin{array}{l}\text { No } \\
\text { Available }\end{array}$ & $\begin{array}{l}\text { Used } \\
\text { often }\end{array}$ & $\begin{array}{l}\text { Used } \\
\text { occasionally }\end{array}$ & $\begin{array}{l}\text { Not } \\
\text { used }\end{array}$ & $\begin{array}{l}\text { No in good } \\
\text { state }\end{array}$ & $\begin{array}{l}\text { No } \\
\text { obsolete }\end{array}$ \\
\hline 1 & Journal & 0 & - & - & $\checkmark$ & - & - \\
\hline 2 & Bulletins & 0 & - & - & $\checkmark$ & - & - \\
\hline 3 & $\begin{array}{l}\text { Economics wall maps of } \\
\text { Nigeria, }\end{array}$ & 10 & - & $\checkmark$ & - & - & - \\
\hline 4 & $\begin{array}{l}\text { Economics wall map of } \\
\text { Africa }\end{array}$ & 5 & - & $\checkmark$ & - & - & - \\
\hline 5 & $\begin{array}{l}\text { Economics wall map of } \\
\text { World }\end{array}$ & 5 & - & $\checkmark$ & - & - & - \\
\hline 6 & Newspaper & 0 & - & - & - & - & - \\
\hline 7 & Tape recorder & 2 & $\checkmark$ & - & - & - & - \\
\hline 8 & Cassettes & 0 & - & - & - & - & - \\
\hline 9 & Projector & 5 & - & $\checkmark$ & - & - & - \\
\hline 10 & Computer set & 80 & - & $\checkmark$ & - & - & - \\
\hline 11 & Economics Textbooks & 150 & $\checkmark$ & - & & - \\
\hline 12 & Others instrument aids & 30 & $\checkmark$ & - & - & - & - \\
\hline
\end{tabular}

Table $3 \mathrm{f}$ presented the available facilities and stationeries in 60 secondary schools in Oyo State. Almost all secondary schools do not have journal, cassette, Newspaper and Bulletins in the schools as against the requirement of NERDC for all secondary schools; only 10 schools had Nigeria maps out 
of which most of them make us of that of geography department five (5) had Economics wall maps of Africa and five (5) Economics wall maps of Nigeria of which those materials are use occasionally. Only one school had tape recorder the reason being that it was a special school that comprise both handicapped and were mandated to use it. 80 computer set were on ground which are said to be for 15 schools altogether; only like eight(8) schools has up to good 10 set others were just one/two and were used occasionally. 150 Economics textbook were available in the 60 schools which are teachers copy except for only one school where the old school student bought like 30 copies for. In some of the schools it was the teachers that procure the available teachers copy there not even the government. This finding also revealed that others instructional materials/aids were inadequate in all secondary visited only few teachers was able to improvise by given assignments to draw some Economics graphs and curve and awards mark to it as part of their continuous assessment. Kimeu, Edward and Ronoh (2015) findings revealed that inadequate instructional resources has account for 73(78\%) out of 93 sampled in his work, also $68(73 \%)$ indicate that this has negative influenced on the students' performance.

\section{DISCUSSION OF FINDINGS}

The findings of the study revealed $100 \%$ of Economics Curriculum Contents in Senior Secondary Schools were relevant in the Economics Curriculum Contents of Colleges of Education in Oyo State and fully captured. There were not any content left out of secondary school Economics, that connote that if all those contents were taught well at the colleges of education and pre-service Economics teachers also learnt well they should be able to teach those contents again at secondary schools level. The finding of Oleabhiele (2008) reveals that the curriculum contents of Economics are adequate and are in line with the objective of the nation. But the finding of Bakare (2014) revealed contrary; 64.9\% of Computer Science Education (CSE) Curriculum contents in the Colleges of Education (COE) were relevant in the Computer science of Education Curriculum contents in junior Secondary Schools (JSS). While $35.1 \%$ of CSE curriculum contents of the JSS were not captured at all in the colleges of education curriculum. Eshun, Bordoh, Bassaw and Mensah (2014) there is a differences in how the subject is structured to prepared teachers to teach it at the Junior High School (JHS) level, implying that curriculum contents of Social Studiesof Ghana at JHS with that of curriculum contents of Social Studies at colleges of Education of Ghana were not $100 \%$ related, there were some contents which do not reflected at JHS curriculum. Some of the curriculum contents of Social Studies at the colleges of education were said suitable in preparing the training to teach Civic instead of Social studies itself.

The result of the study as revealed by Bakare (2014) showed that there were adequate, relevance and utilization pattern of available of ICTs facilities in colleges of education in Plateau State. This support the finding of this study that it is possible to have complete $100 \%$ relatedness of curricular contents, while Ok wudishu (2005) were of opinion that non-availability of ICT component would hamper preservice teachers' use of ICTs, he came out from another dimension that having content compliance without congruence with resources may still render the whole implementation baseless. Because one can only give out what have and know which latter culminate in effective teaching/implementation. Although these study do not go into assessing whether all the contents were covered in detail during training because the study revealed complete relevance in the contents it would then be shocking if students could not perform excellently

The result of this study revealed that the lecture method has highest percentage score of $50 \%$ (10 lecturers); 30\% (6 lecturers) used Discussion method while 20\% (4 lecturers) use combination of strategies of which one can conclude that lecturing method is said to be appropriate in teaching in Colleges of Education. But it was discovered also that only 2(10\%) said to be most appropriate (rated at $80-100 \%$ ) in the used of their strategies chosen. That was possible as result of their long year experience, combination of strategies and effective used of it to facilitate learning during teaching process. Their class was lively and students fully participated and actually learned. The result was in agreement with McIntosh (1996) cited by Tom-Lawyer (2014) opine that combination of modes would encourage participation of students and reflect on what is learn. Students were able to demonstrate their mastery level when evaluation of the class was done.

Also, Nine lecturers [9 (45\%)](rated at 60-79\%) were said to be adequately appropriate out of which four (4) of them used lecture method, another four (4) used discussion method which was in line with 
the finding of Rahman, Khalil, Jumani, Ajmal, Malik and Sharif (2011) that discussion method was more effective than lecture method as the post -test result show significant difference in the mean score of both experimental group (Discussion and Lecture method) and control group (Lecture method only) contrary to pretest result that both control group and experimental group that there was no significant different in their performance, while the last one used tutorial and discussion this support the Adetunji (2014) finding that combination of strategies should be used and that reliance on one teaching method is restrictive to students learning. Furthermore, six (6) lecturers (30\%) of them used lecture method although have good mastery of the content but in the aspect of instructional materials and ensuring that teaching is made practical as much were found lacking.

Actually, Colleges of Education should be training ground for the teachers; lecturer should in turn used various strategies to train them which would enhance their effectiveness and being able to handle any recommend strategies in the curriculum. This has negative influence on the trained teacher as majority of them [38 (31.67\%)] as well utilize lecturing most at secondary schools; out of which $32(26.67 \%)$ comprises [24(20\%) plus $8(6.67 \%)$ ] of them were not effective in the used. Teaching methods have to shift from being merely spoon-fed, it should be tailored on how to dig out the inherent ability in students through creative thinking, collaboration exercises, research work and group discussions then we are going to have resourceful teachers in schools that would make learning to take place effectively

The study as well revealed the teaching strategies employed by various Economics teachers in the secondary schools, from $4.2 \mathrm{~b}$ above it was discovered out of 120 Economics teachers none of them was said to be most appropriate in the choice of the strategies while $19(15.83 \%)$ were said to be adequately appropriate (13 interactive and 3 lecture method);results revealed that 33 (27.5\%) teachers were scored to be appropriate in their choice of strategies (19 interactive, 4 lecture, 7 discussion, 2inquiry and Interactive and 1 problem based \& interactive), 54 (45\%) was partially appropriate (20 interactive, 24 lecture and 10 discussion method and 18 (15\%) was not appropriate at all. The problem above could be attributed to inadequacy in the provision of some related materials and teaching aids in the schools, of which many of the lecturers could not improvise so also department were limited in bridging the gap; as result preservice teacher were only taught the content perhaps expect the General Education to take care of the instructional aspect. This neglect has actually contributed to inefficient of many of the trained teachers in secondary schools.

Also, majority of the Economics lecturer in NCE are mostly from cognate discipline of which they are not exposed to the use of teaching aids as such. Similarly many of them lack adequate knowledge on the diversity of teaching methodology and could not use it in the cause of teaching. Adetunji (2014) as well as Adeyemi (2010) supported this view that reliance on one teaching method is restrictive to students learning. If majority of them are educationally incline and perhaps hold their first degree or second degree in Education it would have been very easy for them to teach effectively using instructional resources. Although, some of the NCE have facilities that can make the teaching materials to be easily used but such materials are not available, while many do not know how to actually use it. The study have been able to shed light to the problems confronting Economics curriculum implementation in Oyo State, non-availability of resources right from colleges of education and narrower method of teaching has done much harm to the implementation process.

\section{CONCLUSiON}

Based on the fact and figure of this study, it can be concluded that there was great deal of relatedness between the Economics curriculum contents of Colleges of Education and Senior Secondary Schools, but inadequate supply of instructional materials and others resources in terms of human and nonhuman had great negative influence on the chosen teaching strategies employed by both Economics lecturer and secondary schools teachers respectively which had not help the learners (preservice teachers) to be able to teach secondary schools effectively as 54(45\%) were partially appropriate and $18(15 \%)$ said not appropriately at all in the choice of the teaching method. Only few available resources were of good quality in Colleges of Education as well as senior secondary schools in Oyo State.

\section{RECOMMENDATIONS}

The results from the study and observation made in the course of gathering the data generated some vital recommendation that is important to all education stakeholders in Nigeria. The following recommendations were provided: 
i. There is need for provision of instructional materials and others teaching aids in the schools both in Colleges of Education and Secondary Schools in the state.

ii. There is need for adequate training in the use of many of these resources, seminars should be encouraged to train and demonstrate to them on the usage right from Colleges of Education. Emphasis should be placed on it and compulsory it in the curse of teaching exercise.

iii. The spirit of improvisation should be steered up in the preservice teacher through the education course that meant to train them on preparing of different teaching aids.

iv. There is need for lecturers and secondary schools teachers to diversify their teaching strategies based on the contents to be taught and try to utilize combination of strategies where necessary.

v. Teachers need to update their knowledge in order to accommodate for the present days challenges

\section{REFERENCES}

[1] Adeyemi, B. A. (2010). An Evaluation of Social Studies teaching strategies in Osun State Colleges of Education, Nigeria. Journal of Sociology and Education in Africa 9(2) 129 - 144.

[2] Adegbile, J. A. and Adeyemi, B. A. (2008). Influence of teacher quality variables on Nigeria Primary school Pupils' Achievement in English Language. The African Symposium, 8(2), 108 - 115

[3] Adetunji, O. S. (2014). Student - Centered methods of teaching Architecture students theory of structures in Nigeria Universities. International Journal of Education and Research, 2(10), 437 - 444

[4] Adu, E. O., Ojelabi, S. A.\& Adeyanju.H. (2009).Quantitative ability as correlates of students' academic achievement in secondary school Economics in Oyo State, Nigeria. An International Multi-Disciplinary Journal, Ethiopia, 3 (2), 322 - 333

[5] Bakare, O. O. (2014).Evaluation of Computer Science Education Curriculum in Colleges of Education in Osun State.(Dissertation presented as part of fulfillment of the requirements of the degree of Master of Education, Obafemi Awolowo University Ile Ife).

[6] Caldwell, B. \& Sutton, D. (2010). Review of teacher education and school induction. Second report - full report. Department of Education and Training, Queensland Government.

[7] Caropreso, E. J., \& Haggerty, M. (2000). Teaching economics: A cooperative learning model. College Teaching, 48(2), 69 - 74.

[8] Donaldson, M. L. \& Johnson, S. M. (2011). Teach for America teachers: How long do they teach? Why do they leave? The Phi Delta Kappa, 93 (2), 47-51.

[9] Edem, E. (2004) Educational policies in Nigeria. Lagos: Marks Press.

[10] Ehindero, O.J. (2010). Curriculum, Teaching and Instruction. In O.J. Ehindero, O.O. Ojerinde and Y.A. Ajibade. Currriculum and the Teaching Process, Damas Educational Services, Ghana

[11] Eshun, I., Bordoh, A., Bassaw, T. K., \& Mensah, M. F. (2014). Evaluation of social studies students' learning using formative assessment in selected Colleges of Education in Ghana. British Journal of Education, 2(1), 39-48

[12] Gathumbi, A. M. \&Mosoti, R. O. (2015).Influence of resources and materials on theimplementation of non-formal basic education curriculum at the non-formal education centres in Nairobi, Mombasa and Kisumu cities, Kenya. International Journal of Education and Research, 3(4), 123 - 132.

[13] Kimeu, R. W., Edward, T. \&Ronoh, A. (2015).Influence of Instructional Resources on Secondary School Students' Academic Performance in Makueni County, Kenya. International Journal of Scientific Research and Innovative Technology, 2(1), $70-81$.

[14] McIntosh, N. (1996) Why Do We Lecture? JHPIEGO Strategy Paper No. 2. JHPIEGO. Corporation, Baltimore.

[15] Mkpa, A. (2001) Optimization of Available Teaching and Learning Materials/Facilities. In: Nnolis, O. and Sulaiman, I., Eds., Reassessing the Future Education in Nigeria, ETF Publication, Abuja.

[16] National Commission for College of Education (2012): Curriculum Implementation Frameworks

[17] NERDC (2008). The 9- Year Basic Education Curriculum at a Glance. Lagos: NERDC Press. www.nerdcnigeria.org.

[18] Okwudishu, C.H. (2005). Awareness and use of information and communication technology (ICT) among village secondary school teachers in Aniocha South Local Government Area of Delta State. Abraka: Delta State University. Unpublished B.Sc. (LIS) project. 
[19] Olanipekun, S.S. and Onabanjo, E. O (2015 Curriculum and Reforms. International Journal of Educational Research and Information science 2(3);). Assessment of the NCCE General English Curriculum in the ight of Modern 27-30.

[20] Oleabhiele, E.O. (2008). Strategies for enhancing the teaching of Economics in senior secondary schools in Edo state.Unpublished M.Ed. Dissertation presented to the Department of Arts and Social Science Education, Ebonyi State University.

[21] Ongeri, J.D. (2009) Learner centered teaching economics: Action research study. A dissertation in Adult Education submitted in partial fulfillment of the requirements for the degree of Doctor of Education. Retrieved fromhttps://etda.libraries.psu.edu/paper/9441/5030 on 28th November 2015

[22] Oladejo, M. A, Olosunde, G. R, Ojebisi, A. O. and Isola, O. M. (2011). Instructional Materials and Students' Academic Achievement in Physics: Some Policy Implications. European Journal of Humanities and Social Sciences Vol. 2(1).

[23] Praxis Client Conference (PCC, 2011). Content Knowledge for Teaching: Innovation for the Next Generation of Teaching Assessments. Retrieve on July 28, 2015

[24] Rahman, F., Khalil, J.K., Jumani, N.B., Ajmal, M., Malik, S., \& Sharif, M. (2011). Impact of discussion method on students performance. International Journal of Business and Social $\quad$ Science, 2(7): 84-94.

[25] Report of the Teacher Education Implementation Taskforce (RTEIT, 2012). Queensland Government

[26] Shuaibu, S and Shuaibu, S.S (2015). The impact of educational resources on curriculum implementation in Nigeria.Journal ofEducation, Arts and Humanities, 3(4) pp. 59-63

[27] Shulman, L. (1986). Those who understand: Knowledge growth in teaching. Educational Researcher, 15(2), 4 - 14.

[28] Stephen R. White, D.A (2003). Reconstructionism and Interdisciplinary Global Education: Curricula Construction in a Teilhardian Context. whitesr@boone.net. Download on 26/1/2016 from HTML Document (.htm)

[29] Tom-Lawyer, O. (2014) An Evaluation of the English Language Curriculum of the Nigeria Certificatein Education: A Case Study of a College of Education. Open Journal of Social Sciences, 2, 69-79. http://dx.doi.org/10.4236/jss.2014.27011

[30] Uma, K., Obidike, P. and Ogwuru, H. (2013) Revamping the Nigerian Education Sector for Quality Manpower Development Lessons from Japan. American Journal of Social Issues and Humanities, 3, 330339

[31] West African Examination Chief Examiner Reports. (2009-2014) edition.

\section{AUTHOR'S BIOGRAPHY}

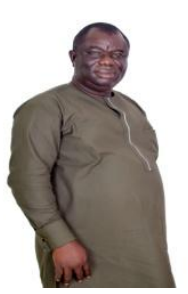

Professor B.A Adeyemi, is the immediate past Director of the Institute of Education, Obafemi Awolowo University, Ile-Ife, Osun State, Nigeria.

His areas of specialization are Social Studies and Educational Evaluation. He has over 170 publications to his credit.

Citation: AdeyemiZaccheaus OJO, Prof. Babatunde Adeniyi ADEYEMI. "Assessment of Economics Curriculum Implementation in Colleges of Education and Secondary Schools in Oyo State" International Journal of Humanities Social Sciences and Education (IJHSSE), vol 7, no. 6, 2020, pp. 130-145. doi: http://dx.doi.org/10.20431/2349-0381.0706015.

Copyright: (C) 2020 Authors. This is an open-access article distributed under the terms of the Creative Commons Attribution License, which permits unrestricted use, distribution, and reproduction in any medium, provided the original author and source are credited. 